\title{
Corneal Refractive Surgery in Patients with a History of Herpes Simplex Keratitis: A Narrative Review
}

This article was published in the following Dove Press journal:

Clinical Ophthalmology

\author{
Majid Moshirfar (DD ${ }^{1-3}$ \\ Dallin C Milner ${ }^{4}$ \\ Preston A Baker (D) $^{5}$ \\ Shannon E McCabe (D) \\ Yasmyne C Ronquillo (D) \\ Phillip C Hoopes ${ }^{\prime}{ }^{\prime}$
}

'Hoopes Vision Research Center, Hoopes Vision, Draper, UT, USA; '2John A. Moran Eye Center, University of Utah School of Medicine, Salt Lake City, UT, USA; ${ }^{3}$ Utah Lions Eye Bank, Murray, UT, USA; ${ }^{4}$ University of Colorado School of Medicine, Aurora, CO, USA; ${ }^{5}$ McGovern Medical School, University of Texas Health Science Center, Houston, TX, USA
Correspondence: Majid Moshirfar

Hoopes Vision Research Center, Hoopes

Vision, II 820 S. State Street Suite \#200,

Draper, UT 84020, USA

Tel +l 80I-568-0200

Email Cornea2020@me.com

\begin{abstract}
The incidence of herpes simplex keratitis (HSK) in patients following corneal refractive surgery is higher than in the general population, and several case reports of ocular morbidity in HSK infection following corneal refractive surgery have been published. HSK is listed by the American Academy of Ophthalmology as a relative contraindication to corneal refractive surgery, although specifics have not been further elucidated. This review summarizes the current literature regarding reactivation of HSK following corneal refractive surgery and provides a guideline for considering corneal refractive surgery in a patient with a previous history of HSK. Based on the current literature, we recommend that corneal refractive surgery is appropriate for patients with a history of HSK without multiple recurrences who have had no evidence of disease for at least one year. In addition to a thorough history and physical examination, we also recommend these patients begin $400 \mathrm{mg}$ twice daily of oral acyclovir or valacyclovir $500 \mathrm{mg}$ once daily for two weeks prior to surgery and continue this regimen for at least two weeks postoperatively or while on topical steroids.
\end{abstract}

Keywords: herpetic keratitis, LASIK, PRK, PTK, herpes prophylaxis, SMILE, HSV, shingles, varicella zoster, cytomegalovirus, CMV

\section{Introduction}

Herpes simplex keratitis (HSK) is the most common infectious cause of blindness. ${ }^{1}$ Annually, HSK affects approximately one million people globally. ${ }^{2}$ In the United States, 500,000 people are affected by HSK annually. ${ }^{3}$ While many recover without permanent visual impairment, $15 \%$ will develop severe complications such as persistent pain, dry eye, corneal scarring, and vision loss. ${ }^{4,5}$ HSK can be further divided anatomically into epithelial, stromal, or endothelial involvement. Epithelial involvement typically causes pain and redness, while stromal and endothelial HSK can cause vision loss. ${ }^{6}$ Stromal HSK only represents two percent of the initial HSV ocular presentations but causes $20-61 \%$ of recurrent disease. ${ }^{7}$ Disease recurrence, a major driving factor for these adverse outcomes, is common. Young et al found that the risk of recurrence of ocular HSV was $27 \%, 50 \%$, and $57 \%$ at one, five, and ten years, respectively, and increased to $38 \%$ and $67 \%$ at one and five years, respectively, if the initial episode was followed by recurrence. ${ }^{8}$ Due to the high risk of complications with recurrence, understanding potential triggers and possible prophylaxis has been the focus of many researchers.

The Herpetic Eye Disease Study (HEDS), one of the largest multicenter randomized control trials studying ocular HSV to date, found that $400 \mathrm{mg}$ of acyclovir twice 
Table I Reports of Post-PRK HSK

\begin{tabular}{|c|c|c|c|c|c|c|}
\hline Study & $\begin{array}{l}\text { Number of (+) } \\
\text { Eyes }\end{array}$ & $\begin{array}{l}\text { Previous } \\
\text { HSV }\end{array}$ & $\begin{array}{l}\text { Time to Dx s/p } \\
\text { Surgery }\end{array}$ & $\begin{array}{l}\text { Clinical } \\
\text { Presentation }\end{array}$ & Treatment & $\begin{array}{l}\text { Final } \\
\text { VA }\end{array}$ \\
\hline McDonnell - Case Series ${ }^{19}$ & $1 / 4$ & Yes & 4 weeks & $\begin{array}{l}\text { Epithelial herpes } \\
\text { keratitis }\end{array}$ & Topical steroids & - \\
\hline Rao - Case Series ${ }^{18}$ & $1 / 139$ & No & - & - & Topical steroids & - \\
\hline Wulff - Case Report ${ }^{21}$ & $1 / 1$ & Yes; labialis & I week & Epithelial defect & $\begin{array}{l}\text { Topical acyclovir hourly for } \\
2 \text { weeks }\end{array}$ & - \\
\hline
\end{tabular}

Abbreviations: PRK, photorefractive keratectomy; HSK, herpes simplex keratitis; Dx, diagnosis; s/p, status post; HSV, herpes simplex virus; VA, visual acuity.

daily reduced the rate of all types of ocular HSV recurrence to $19 \%$ compared to $32 \%$ in the placebo group. ${ }^{9}$ The HEDS trial also evaluated psychological stress, infection, and exposure to sunlight as potential ocular HSV triggers. Cohen et al did not find any association with recurrence and these potential triggers. ${ }^{10}$ However, animal studies suggest that excimer laser keratectomy and laser-assisted in situ keratomileusis (LASIK) may induce reactivation of ocular HSV. ${ }^{11,12}$ These data, along with several case reports and case series, are likely the reason that the American Academy of Ophthalmology (AAO) has listed a history of HSV keratitis as a relative contraindication for corneal refractive surgery. ${ }^{13}$ However, ocular herpes is a broad diagnosis and could include conjunctivitis, epithelial keratitis, stromal keratitis, endotheliitis, retinitis, uveitis, and blepharitis. ${ }^{14}$ Additionally, patients with HSV can benefit from improved visual acuity with negligible or low risk of recurrence if proper steps are taken. ${ }^{15-17}$ In this article, we will review all the case reports, animal studies, prospective studies and retrospective studies in the literature of HSV ocular disease following corneal refractive surgery, with an emphasis on LASIK, PRK, and SMILE. Additionally, we will outline our preferred practice pattern for identifying patients who can safely undergo surgery.

\section{Methods}

A literature search of PubMed, AGRIS, Asian Digital Library, and Google Scholar from 1974-2020 was performed using search terms such as herpetic keratitis, human herpes virus, cytomegalovirus, CMV, varicella zoster, VZV, herpes zoster ophthalmicus, refractive surgery, excimer laser, PTK, PRK, SMILE, and LASIK. In all, the literature review yielded 24 case reports, five prospective case series, two retrospective case series, one uncontrolled trial, and five animal studies. Articles were written mainly in English; however, three case reports in Spanish, Portuguese, and Turkish were also included.

\section{Post-PRK Herpetic Ocular Disease}

A review of the literature yielded three animal studies, two prospective case series, one case report, and one retrospective study that suggest excimer laser photorefractive keratectomy (PRK) as a trigger of HSV keratitis. ${ }^{11,18-23}$ A summary of the case series and case report findings of post-PRK HSK can be found in Table 1. Within the animal studies, Pepose et al found that excimer laser pulses, corneal epithelial scraping, and combined corneal epithelial scraping all caused increased HSV shedding in mice. ${ }^{22}$ Dhaliwal et al demonstrated that epithelial scraping and excimer laser pulses caused a $45 \%$ reactivation rate versus only $5.6 \% \mathrm{HSV}$ recurrence in control rabbits. ${ }^{11}$ Additionally, according to Dr. Asbell's animal studies, it would appear that the excimer laser plays a major and specific role in the reactivation of HSK. Asbell demonstrated that de-epithelialization alone did not reactivate HSV in rabbits but that de-epithelialization coupled with excimer laser resulted in $66.67 \%$ HSV keratitis reactivation rate providing strong evidence that the excimer laser was the trigger for recurrence. ${ }^{23}$ It has been long established that B wavelength ultra-violet light (UVB) can trigger HSV recurrence in humans. ${ }^{24}$ Asbell's study was the first to suggest conclusively that the $193 \mathrm{~nm}$ UVC light could also reactivate HSV possibly explaining the reactivation of HSK seen in radial keratectomy (RK), PRK, PTK, and LASIK. $^{20,23,25}$

In humans, the data have been less clear. Nagy et al found after reviewing 13,200 post-PRK eyes that the incidence of post-PRK HSV keratitis was $0.14 \%$ (19 of 13,200), much higher than the incidence of $0.0315 \%$ in the general population. ${ }^{20,26}$ Seventy-eight percent of patients presented within 15 weeks of surgery and none of the patients had documented HSV keratitis prior to surgery. ${ }^{20}$ Two case 
series and one case report were reported in the literature. ${ }^{18,19,21}$ Of the two case series only two out of 143 eyes that had undergone PRK presented with HSK following surgery. ${ }^{18,19}$ McDonnell et al's study was the only report of a patient with a positive herpetic ocular disease history before PRK. ${ }^{19}$ Wulff et al did document that their patient had herpes labialis; however, non-ocular herpetic infections are not contraindications to corneal refractive surgery. ${ }^{21}$

\section{Post-PTK Herpetic Ocular Disease}

Phototherapeutic keratectomy (PTK) uses the same excimer laser as PRK and is indicated in patients with corneal opacities, irregularities, or any corneal refractive error that is caused by trauma, previous surgery, or disease. ${ }^{27}$ As recurrent HSK commonly causes scarring, 86\% (12/14) of the patients who developed HSK post-PTK had previous ocular herpetic disease in the seven case reports found in the literature. $^{18,28-34}$ A summary of the case reports can be found in Table 2. Interestingly, at least five of the 14 reported cases involved reactivation of stromal keratitis. This reactivation is significant as the HEDS trial found that patients with a history of ocular herpetic disease, but not HSV stromal keratitis, only had recurrence rates of 3\% compared to recurrence rates of $28 \%$ in patients with a history of HSV stromal keratitis. ${ }^{35}$ In the longest epidemiologic study to date, Young et al found that most adverse outcomes, including scarring, did not occur until after, on average, four recurrences. ${ }^{8}$ Additionally, disease recurrence is a strong predictor of subsequent recurrences. ${ }^{8}$ Since the patients in these studies were undergoing PTK for scarring due to HSK, they were already at high risk of recurrence even without surgery. Nevertheless, Deai et al did find that PTK was sufficient to cause levels of viral shedding seen in reactivated herpetic ocular disease in one HSV positive patient. ${ }^{33}$ If PTK and lasers in other corneal refractive procedures do cause increased viral shedding, it is significant as Perng et al found that high viral loads in tears precede recurrent $\mathrm{HSK}$ in rabbits. ${ }^{36}$

\section{Post-LASIK Herpetic Ocular Disease}

Eleven case reports and one retrospective study discussed post-LASIK ocular herpes in 19 patients. $^{25,30,37-48}$ A summary of the findings of each paper can be found in Table 3. Of note, the presentation of HSK ranged from one day post-LASIK to 28 months, with the median being four weeks. Of the infections, 37\% (7/19) were presumed epithelial HSK, 32\% (6/19) stromal HSK, 11\% (2/19) disciform endotheliitis, 16\% (3/19) keratouveitis, and $5 \%(1 / 19)$ polymicrobial. Where reported, only $56 \%$ (10/19) of patients were previously diagnosed with HSV infection, and only three patients had previous ocular manifestations of the

Table 2 Reports of Post-PTK HSK

\begin{tabular}{|c|c|c|c|c|c|}
\hline Study & $\begin{array}{l}\text { Previous } \\
\text { HSV }\end{array}$ & $\begin{array}{l}\text { Time to Dx s/p } \\
\text { Surgery }\end{array}$ & Clinical Presentation & Treatment & Final VA \\
\hline Fagerholm ${ }^{28}$ & Yes & - & $\begin{array}{l}\text { Case series with } 5 / 20 \text { eyes developing } \\
\text { HSK reactivation }\end{array}$ & Topical steroids, topical acyclovir & Decreased \\
\hline Tervo $^{29}$ & Yes & 8 days & Stromal herpes keratitis & - & - \\
\hline $\mathrm{Lu}^{30}$ & No & 3 weeks & Epithelial herpes keratitis & Topical acyclovir 5x/day & - \\
\hline Vrabecl $1^{31}$ & Yes & 12 weeks & Stromal herpes keratitis & Topical steroids & Decreased \\
\hline Vrabec $2^{31}$ & Unclear & 12 weeks & Epithelial herpes keratitis & Topical steroids & Unchanged \\
\hline Vrabec $3^{31}$ & Yes & 16 weeks & Epithelial herpes keratitis & Topical steroids, topical trifluridine & Decreased \\
\hline Vrabecl $1^{32}$ & Yes & 18 months & Epithelial herpes keratitis & Topical steroids, topical trifluridine & Decreased \\
\hline Starr $I^{34}$ & Yes & 16 weeks & Herpetic keratouveitis & $\begin{array}{l}\text { Topical steroids, oral acyclovir, } \\
\text { topical trifluridine }\end{array}$ & Decreased \\
\hline Starr $2^{34}$ & Yes & 14 months & Herpetic keratouveitis & $\begin{array}{l}\text { Topical steroids, oral acyclovir, } \\
\text { topical trifluridine }\end{array}$ & Decreased \\
\hline Starr $3^{34}$ & Yes & 17 months & Herpetic keratouveitis & $\begin{array}{l}\text { Topical steroids, oral acyclovir, } \\
\text { topical trifluridine }\end{array}$ & Decreased \\
\hline
\end{tabular}

Abbreviations: PTK, phototherapeutic keratectomy; HSK, herpes simplex keratitis; Dx, diagnosis; s/p, status post; VA, visual acuity. 
Table 3 Reports of Post-LASIK HSK

\begin{tabular}{|c|c|c|c|c|c|}
\hline Study & $\begin{array}{l}\text { Previous } \\
\text { Infection }\end{array}$ & $\begin{array}{l}\text { Time to } \\
\text { Dx s/p } \\
\text { Surgery }\end{array}$ & Clinical Presentation & Treatment & $\begin{array}{l}\text { Final } \\
\text { VA }\end{array}$ \\
\hline Davidorf ${ }^{44}$ & Yes; ocular & I day & Epithelial dendrites & $\begin{array}{l}\text { Trifluridine every } 2 \text { hours while awake for I week, } \\
\text { famciclovir } 375 \mathrm{mg} 3 \times \text { /day for } 2 \text { weeks, artificial } \\
\text { tears }\end{array}$ & $20 / 20$ \\
\hline Perry $^{42}$ & Yes; ocular & 10 days & $\begin{array}{l}\text { Cornea edema, corneal } \\
\text { perforation }\end{array}$ & $\begin{array}{l}\text { Oral acyclovir } 2 x / \text { day, prednisolone I } \% 4 x / \text { day, } \\
\text { ofloxacin } 4 x / \text { day, cyclosporine A } 0.5 \% \text {, lamellar } \\
\text { keratoplasty }\end{array}$ & $20 / 50$ \\
\hline Levyl $^{46}$ & Yes; labialis & 6 weeks & $\begin{array}{l}\text { Corneal edema, KP, epithelial } \\
\text { dendrites }\end{array}$ & $\begin{array}{l}\text { Topical steroids } 8 x / \text { day, acyclovir } 400 \mathrm{mg} 5 x / \text { day, } \\
\text { topical acyclovir } 5 x / \text { day }\end{array}$ & $20 / 30$ \\
\hline $\operatorname{Levy}^{46}$ & Yes; ocular & 2 years & $\begin{array}{l}\text { Pain, stromal edema, DM folds, } \\
\text { epithelial dendrites }\end{array}$ & $\begin{array}{l}\text { Oral valacyclovir } 3 \mathrm{~g} 3 \mathrm{x} / \text { day, dexamethasone } 4 \mathrm{x} / \text { day, } \\
\text { topical acyclovir } 5 \mathrm{x} / \text { day }\end{array}$ & $20 / 20$ \\
\hline $\mathrm{Lu}^{30}$ & No & 4 weeks & $\begin{array}{l}\text { Pain, blurred vision, epithelial } \\
\text { dendrites }\end{array}$ & $\begin{array}{l}\text { Topical acyclovir } 5 x / \text { day, oral acyclovir } 200 \mathrm{mg} \mathrm{5x/} \\
\text { day for } 10 \text { days }\end{array}$ & $20 / 20$ \\
\hline Kamburoglu ${ }^{45}$ & No & 8 days & $\begin{array}{l}\text { Epithelial ulcer, stromal infiltrate, } \\
\mathrm{KP} \text {, corneal edema }\end{array}$ & $\begin{array}{l}\text { Topical steroids hourly, topical acyclovir } 5 x / \text { day, oral } \\
\text { valacyclovir } 400 \mathrm{mg} 5 x / \text { day for } 2 \text { months }\end{array}$ & - \\
\hline Moshirfarl ${ }^{25}$ & No & I day & $\begin{array}{l}\text { Epithelial dendrites, hypopyon, } \\
\text { disciform endotheliitis }\end{array}$ & $\begin{array}{l}\text { Topical trifluridine, oral valacyclovir } 500 \mathrm{mg} 2-3 \times \text { / } \\
\text { day, prednisolone } 1 \% \text {, systemic corticosteroids }\end{array}$ & $\begin{array}{l}20 / \\
200\end{array}$ \\
\hline Moshirfar $2^{25}$ & No & 21 weeks & Epithelial dendrites & $\begin{array}{l}\text { Topical trifluridine, oral valacyclovir } 500 \mathrm{mg} 2-3 \times \text { / } \\
\text { day, prednisolone } 1 \%\end{array}$ & $20 / 40$ \\
\hline Moshirfar $3^{25}$ & No & 25 weeks & Epithelial dendrites & $\begin{array}{l}\text { Topical trifluridine, oral valacyclovir } 500 \mathrm{mg} 2-3 \times \text { / } \\
\text { day, prednisolone } 1 \%\end{array}$ & $20 / 30$ \\
\hline Moshirfar $4^{25}$ & No & I week & Epithelial dendrites & $\begin{array}{l}\text { Topical trifluridine, oral valacyclovir } 500 \mathrm{mg} 2-3 \times \text { / } \\
\text { day, prednisolone } 1 \%\end{array}$ & $20 / 40$ \\
\hline Moshirfar $5^{25}$ & No & 2 weeks & Epithelial dendrites & $\begin{array}{l}\text { Topical trifluridine, oral valacyclovir } 500 \mathrm{mg} 2-3 \times \text { / } \\
\text { day, prednisolone } 1 \%\end{array}$ & $20 / 30$ \\
\hline Jain $^{39}$ & Yes; ocular & 5 weeks & $\begin{array}{l}\text { Corneal edema, KP, disciform } \\
\text { endotheliitis }\end{array}$ & Oral acyclovir $400 \mathrm{mg} 5 x /$ day, prednisolone $1 \%$ & $20 / 30$ \\
\hline Gomez $^{43}$ & Yes; labialis & I day & Epithelial dendrites & Topical acyclovir $5 x /$ day & - \\
\hline Arora $^{41}$ & No & 2 weeks & $\begin{array}{l}\text { Hypopyon, corneal edema, KP, DM } \\
\text { folds, stromal infiltrates, flap } \\
\text { necrosis }\end{array}$ & Topical steroids, oral valacyclovir $1000 \mathrm{mg} 2$ x/day & $20 / 30$ \\
\hline Srirampur ${ }^{47}$ & Yes; ocular & 20 weeks & $\begin{array}{l}\text { Pain, redness, photophobia, ring- } \\
\text { like infiltrate under flap and } \\
\text { scarring }\end{array}$ & $\begin{array}{l}\text { Oral acyclovir } 400 \mathrm{mg} 5 x / \text { day, prednisolone } \mid \% 4 x / \\
\text { day, atropine } 3 x / \text { day }\end{array}$ & $20 / 20$ \\
\hline Gupta $^{48}$ & - & - & $\begin{array}{l}\text { Polymicrobial keratitis } \\
\text { (S. epidermidis, F. solani, HSV) }\end{array}$ & Keratoplasty & $20 / 40$ \\
\hline Goto $^{37}$ & Yes; ocular & 10 months & Herpetic keratouveitis & Topical betamethasone, topical acyclovir & $20 / 13$ \\
\hline Nakano ${ }^{38}$ & Yes; ocular & 28 months & Herpetic keratouveitis & $\begin{array}{l}\text { Oral acyclovir } 2 \mathrm{~g} \text {, oral prednisone } 60 \mathrm{mg} \text {, } \\
\text { prednisolone } 1 \%\end{array}$ & $20 / 20$ \\
\hline Orucoglu ${ }^{40}$ & Yes; ocular & - & Disciform endotheliitis & Antiviral, topical dexamethasone & - \\
\hline
\end{tabular}

Abbreviations: LASIK, laser-assisted in situ keratomileusis; HSK, herpes simplex keratitis; Dx, diagnosis; s/p, status post; KP, keratic precipitate; DM, Descemet membrane; HSV, herpes simplex virus. 
disease. While most patients recovered vision to $20 / 40$ or better, one patient had a final vision of $20 / 200 .^{25}$

\section{Post-SMILE Herpetic Ocular Disease}

Small-incision lenticule extraction (SMILE) uses a femtosecond laser to create small corneal incisions circumventing the need to create a flap, as in LASIK. ${ }^{49}$ SMILE was first performed and pioneered by Sekundo et al. There has only been one reported case of possible HSK post-SMILE. ${ }^{50,51}$ The patient presented three days after undergoing SMILE with decreased vision, pain, and decreased corneal sensitivity. Notably, she had no signs of ulceration or discharge; fungal and bacterial cultures were negative. Idiopathic noninfectious lamellar keratitis was the most likely diagnosis; however, herpes keratitis could not be ruled out due to decreased corneal sensation, stromal involvement, and appearance on OCT. She was treated with dexamethasone $4 \mathrm{mg}$ subconjunctival injections and valacyclovir $3 \mathrm{~g}$ daily for 15 days. $^{51}$

\section{Post Refractive Surgery Reactivation of Other Human Herpes Viruses}

While herpes simplex virus 1 is the most common cause of ocular disease, other herpes viruses such as herpes simplex virus 2, cytomegalovirus (CMV or HHV5), varicella zoster virus (VZV or HHV3), and Epstein-Barr virus (EBV or HHV4) are all known to cause ocular pathology. ${ }^{52}$ However, only three case studies were found in the literature demonstrating reactivation of CMV and VZV after corneal refractive surgery. ${ }^{53-55}$ The reactivation of VZV occurred two months after LASIK, with the patient making a full recovery after treatment with valacyclovir $500 \mathrm{mg}$ twice daily and topical acyclovir twice daily. ${ }^{54}$ In a separate case report, Kaufman et al reported a patient with a previous corneal scar due to herpes zoster ophthalmicus (HZO) who underwent PTK, PRK, and LASIK without reactivation. ${ }^{56} \mathrm{HZO}$, the reactivation of VZV in the ophthalmic division of the trigeminal nerve, most commonly presents as keratitis, conjunctivitis, and uveitis. Similar to HSK, studies report high recurrence rates ranging from $31-51 \%$ in the first six years following primary infection. ${ }^{57,58}$ Treatment of HZO is started within 72 hours of onset with $1000 \mathrm{mg}$ of valacyclovir three times per day, acyclovir $800 \mathrm{mg}$ five times per day, or famciclovir $500 \mathrm{mg}$ three times per day for one week. ${ }^{59}$ Vaccination is the preferred primary prevention and some reports suggest the efficacy of oral acyclovir for secondary prophylaxis. ${ }^{60,61}$

The activation of CMV corneal endotheliitis occurred three weeks post-LASIK in a patient who presented with blurred vision and increased intraocular pressure (IOP) of $32 \mathrm{mmHg}$. Anterior uveitis was treated with topical dexamethasone $0.1 \%$ and moxifloxacin $0.5 \%$, which then resolved after two weeks. The patient subsequently presented twice more before the diagnosis of CMV endotheliitis was made and was successfully treated with ketorolac tromethamine $0.5 \%$ four times a day and ganciclovir $0.15 \%$ five times a day. The patient was offered oral acyclovir which was declined due to economic reasons. ${ }^{53}$ The patient had no known history of CMV and activation was believed to be due to local immunosuppression secondary to the steroids received, similar to cases seen after cataract surgery and corneal transplantation. ${ }^{53,62,63}$ A similar case reported by Bacsal et al discussed a patient with anterior uveitis and increased IOP two months after LASIK. The patient was eventually diagnosed with CMV uveitis and treated with oral valganciclovir and topical rimexolone for 10 weeks. ${ }^{55}$ Although CMV retinitis is the most commonly recognized ocular manifestation, CMV corneal endotheliitis, and uveitis are the most common ocular manifestations in immunocompetent patients. ${ }^{64}$ Treatment of CMV endotheliitis is valganciclovir $900 \mathrm{mg}$ twice daily until the eye becomes quiet and then can be decreased to once per day for one year. Blood counts, liver enzymes, and creatinine should be measured prior to prescription as valganciclovir can cause bone marrow depression, hepatotoxicity, and renal toxicity. Additionally, topical corticosteroids are used to manage inflammation and antiglaucoma medications can be used for increased IOP. ${ }^{65}$

One case of Kaposi's sarcoma was reported in the literature in a patient who had LASIK four years before who presented with bilateral subconjunctival hemorrhagic lesions. However, the patient was discovered to be HIV positive without treatment and this was believed to be the cause of the disease, not previous corneal refractive surgery. ${ }^{66}$ One possible case of EBV infection following PTK was reported in the literature. The patient presented with glare, photophobia, and subepithelial opacities and was treated with fluorometholone drops for presumed epidemic keratoconjunctivitis (EKC); however, EBV could not be ruled out. ${ }^{67}$

\section{Corneal Refractive Surgery HSV Prophylaxis} While there is strong evidence to suggest that oral acyclovir reduces the recurrence of ocular HSV, there are few studies that discuss prophylaxis prior to refractive surgery. In our literature review, we found only three studies and 
two animal models that had examined prophylactic treatment as a method to prevent HSV reactivation. ${ }^{15-17,23,68}$ Their results are summarized in Table 4. As evidenced, treatment regimens varied widely regarding dosing as well as pre- and postoperative treatment course duration. However, all of the studies used oral acyclovir or valacyclovir as a prophylactic agent. In the Dhaliwal et al animal model, they demonstrated that acyclovir reduced HSV-1 positive eyes from $35.3 \%$ of the control group to $6.2 \%$ of the treatment group after LASIK. ${ }^{68}$ Asbell reported even stronger evidence for prophylactic use of valacyclovir with no reactivation in her animal model. ${ }^{23}$ Although the human studies involved different antivirals (valacyclovir, oral and topical acyclovir, famciclovir) and dosing protocols (oral acyclovir 800 TID, valacyclovir 500 mg BID), all studies showed no reactivation.$^{15-17}$

Regarding other ocular surgeries, there is little consensus for prophylactic dosing, choice of pharmacologic agent, and length of treatment. Sykakis et al found that while $92.5 \%$ of cataract surgeons prescribe oral acyclovir perioperatively for patients with prior HSV keratitis, there was little consensus on dosage or timing. ${ }^{69}$ Yu et al recently published a prospective case series studying the effects of high dose acyclovir $800 \mathrm{mg}$ twice per day

Table 4 Prophylactic HSV Treatment - Human and Animal Trials

\begin{tabular}{|c|c|c|c|c|c|}
\hline Study & $\begin{array}{l}\text { Study } \\
\text { Design }\end{array}$ & $\begin{array}{l}\text { Previous } \\
\text { Infection }\end{array}$ & $\begin{array}{l}\text { Number } \\
\text { of } \\
\text { Subjects/ } \\
\text { Patients }\end{array}$ & Treatment & Clinical Outcome \\
\hline \multirow[t]{5}{*}{ Asbell ${ }^{23}$} & \multirow[t]{5}{*}{$\begin{array}{l}\text { RCT_Animal } \\
\text { model }\end{array}$} & \multirow[t]{5}{*}{ Inoculation } & Group I: 8 & $\begin{array}{l}\text { Group I: De-epithelialization, IP saline for } \\
\text { I } 4 \text { days }\end{array}$ & Group I: $0 \%$ reactivation \\
\hline & & & Group 2: 15 & $\begin{array}{l}\text { Group 2: De-epithelialization, laser, saline } \\
\text { for } 14 \text { days }\end{array}$ & Group 2: $66.67 \%$ reactivation \\
\hline & & & Group 3: 8 & $\begin{array}{l}\text { Group 3: De-epithelialization, laser, } \\
\text { valacyclovir } 50 \mathrm{mg} / \mathrm{kg} / \text { day for } 14 \text { days }\end{array}$ & Group 3: $50.00 \%$ reactivation \\
\hline & & & Group 4: 6 & $\begin{array}{l}\text { Group 4: De-epithelialization, laser, } \\
\text { valacyclovir } 100 \mathrm{mg} / \mathrm{kg} / \text { day for } 14 \text { days }\end{array}$ & Group 4: $16.67 \%$ reactivation \\
\hline & & & Group 5: 6 & $\begin{array}{l}\text { Group 5: De-epithelialization, laser, } \\
\text { valacyclovir } 150 \mathrm{mg} / \mathrm{kg} / \text { day for } 14 \text { days }\end{array}$ & Group 5: $0 \%$ reactivation \\
\hline \multirow[t]{4}{*}{ Dhaliwal $^{68}$} & \multirow{4}{*}{$\begin{array}{l}\text { RCT - Animal } \\
\text { model }\end{array}$} & \multirow[t]{4}{*}{ Inoculation } & & Valacyclovir postop: & \\
\hline & & & Group I: 16 & Group I: $100 \mathrm{mg} / \mathrm{kg} /$ day for 7 days & Group I: $6.2 \%$ reactivation \\
\hline & & & Group 2: 16 & Group 2: $200 \mathrm{mg} / \mathrm{kg} /$ day for 7 days & Group 2: $6.2 \%$ reactivation \\
\hline & & & Control: 17 & Control postop: saline for 7 days & Control: $35.3 \%$ reactivation \\
\hline Jarade $^{15}$ & $\begin{array}{l}\text { Prospective, } \\
\text { interventional } \\
\text { case series }\end{array}$ & HSK & 3 & $\begin{array}{l}\text { Oral acyclovir } 800 \mathrm{mg} 3 x / \text { day I week } \\
\text { preoperatively, } 800 \mathrm{mg} 3 x / \text { day and topical } \\
\text { acyclovir at bedtime } 2 \text { weeks } \\
\text { postoperatively }\end{array}$ & $\begin{array}{l}\text { No recurrence of HSK } \\
\text { Preoperative BCVA: 20/25, 20/50, 20/ } \\
120 \\
\text { Postoperative: } 20 / 20,20 / 20,20 / 50\end{array}$ \\
\hline $\begin{array}{l}\text { De Rojas } \\
\text { Silva }^{16}\end{array}$ & $\begin{array}{l}\text { Uncontrolled } \\
\text { trial }\end{array}$ & HSK & 5 & $\begin{array}{l}\text { Valacyclovir } 500 \mathrm{mg} 2 \times / \text { day for I week } \\
\text { preoperatively and } 2 \text { weeks } \\
\text { postoperatively, } 0.3 \% \text { ofloxacin } 4 x / \text { day for } 5 \\
\text { days, topical acyclovir Ix/day for } 2 \text { weeks }\end{array}$ & $\begin{array}{l}\text { No recurrence of HSK. Mean } \\
\text { preoperative SE: }-3.2 \text { diopters }(-1.75 \\
\text { to }-6 \text { D). Postoperative UCVA } 20 / 20 \text { - } \\
25\end{array}$ \\
\hline $\begin{array}{l}\text { De Rojas } \\
\text { Silva }{ }^{17}\end{array}$ & $\begin{array}{l}\text { Retrospective } \\
\text { case series }\end{array}$ & HSK & 13 & $\begin{array}{l}\text { Valacyclovir, oral acyclovir, famciclovir, and } \\
\text { topical acyclovir started } 2 \text { days to } 2 \text { weeks } \\
\text { prior to surgery, and regimens } \\
\text { discontinued } 5 \text { days to } 5 \text { months postop }\end{array}$ & $\begin{array}{l}\text { No recurrence of HSK. Mean } \\
\text { preoperative SE: }-2.46 \text { diopters }(-1 \mathrm{I} \\
\text { to }+6.25 \mathrm{D}) \text {. Mean postoperative SE: } \\
-0.12(-1.25 \text { to }+1.25 \mathrm{D})\end{array}$ \\
\hline
\end{tabular}

Abbreviations: HSV, herpes simplex virus; RCT, randomized control trial; IP, intraperitoneal; HSK, herpes simplex virus keratitis; BCVA, best corrected visual acuity; SE, standard error; D, diopter; UCVA, uncorrected visual acuity. 
beginning three months prior to keratoplasty and then increased to five times per day for three months following surgery. The study showed low recurrence rates in the grafts $(7.8 \%)$ especially compared to previous studies done by Goldblum et al $(15.8 \%)$ and $\mathrm{Wu}$ et al $(37.7 \%) .^{70-72}$ Nevertheless, such long treatment duration of acyclovir must be weighed against increasing HSV resistance. ${ }^{73}$ Van Velzen et al reported resistance rates greater than $28 \%$ in patients who had used acyclovir prophylactically for more than one year. ${ }^{74}$ Additionally, Rousseau et al found that $83 \%$ of patients with relapsing HSK despite appropriate prophylaxis had viruses that were genetically resistant to acyclovir. ${ }^{75}$ As thymidine kinase is believed to confer resistance to acyclovir, cross-resistance can also be seen with ganciclovir. ${ }^{76}$ In these patients, foscarnet, cidofovir, and trifluridine can be considered to treat active infection. ${ }^{75,77,78}$

\section{Pathogenesis of Post Refractive Surgery HSK}

Two large retrospective studies that each reviewed over 10,000 eyes found that the incidence of HSK is far greater post-PRK $(0.14 \%$ vs $0.031 \%)$ and post-LASIK $(0.048 \%$ vs $0.031 \%$ ) when compared to the general population..$^{20,25,26}$ Although the exact mechanism is unknown, it is theorized that immunosuppression from topical steroids and neuronal cell death caused by the excimer laser and surgical trauma as well as immunosuppression caused by topical steroids lead to reactivation. ${ }^{23,79,80}$

\section{Authors' Guidelines Initial Evaluation}

Ask specifically about general and ocular HSV infections. While primary ocular HSV infections can occur, they are rare and usually present early in life. ${ }^{4}$ Typically, infections arise from the activation of a dormant infection in the trigeminal ganglion after a non-ocular infection. ${ }^{5}$ In addition to affecting the cornea, HSV can affect all other major ocular tissues, including the conjunctiva, lids, uveal tract, and the retina. ${ }^{81}$ Thus, it is important to ask which part of the eye was affected. De Rojas et al demonstrated that even without prophylaxis, no herpetic reactivation occurs with previous HSV blepharitis. ${ }^{17}$

Serologic testing prior to corneal refractive surgery is not recommended. In the US, primary infection with HSV1 and HSV-2 occurs in the vast majority of individuals by the age of 60, and many of these infections are asymptomatic. $^{82}$ Additionally, HSV-1 DNA has been isolated in the tears and the trigeminal nerve ganglia of individuals who have no reported history of ocular HSV1 disease. $^{83}$ Prophylaxis is not recommended for these patients. However, within our review of the case reports, $33 \%$ (12/36) of patients who presented with HSV keratitis post-refractive surgery had no known prior HSV infection.

Surgery is not recommended for patients with multiple recurrences. Young et al reported that the risk of subsequent recurrence increases with each HSK reactivation; therefore, we suggest that corneal refractive surgeons exercise extreme caution when considering elective surgery on patients with previous HSK and two or more recurrences.

Delay surgery at least one year from most recent HSV recurrence. If the patient does have a positive history of HSK, they should be asked how long it has been since their most recent recurrence. In the two small studies reporting no HSK reactivation post-LASIK, only patients who did not report recurrence within one year prior to surgery were included. ${ }^{15,16}$

\section{Physical Examination}

Patients with no corneal haze, nummular keratopathy, or signs of neovascularization can be considered candidates for corneal refractive surgery. Examination should include visual acuity, a comprehensive external examination of the eyelids, corneal sensation testing, and slit-lamp examination. Patients with a history or suspected history of HSK should have corneal sensation testing because sensation is often impaired post-infection. Slit-lamp examination should include evaluation for stromal haze, nummular keratopathy, pannus, and neovascularization as these can be signs of previous viral infection. Additionally, attention should be directed toward any endothelial changes as possible evidence of endotheliitis. ${ }^{2,84}$

\section{Prophylaxis}

For LASIK, oral acyclovir $400 \mathrm{mg}$ twice daily or valacyclovir $500 \mathrm{mg}$ once daily for two weeks before and continued for 2 weeks after surgery is suggested. For PRK, SMILE, and other corneal refractive procedures, begin oral acyclovir $400 \mathrm{mg}$ twice daily or valacyclovir $500 \mathrm{mg}$ once daily for two weeks before surgery and continue course postoperatively until cessation of topical steroids. Without the benefit of randomized control trials or consensus within the scientific literature, we recommend the dosing suggested by HEDS trial for HSK prophylaxis. We recommend starting the prophylaxis 
two weeks prior to surgery as supported by the prospective study of De Rojas et al wherein no recurrence was seen. $^{16}$ Although intraocular corticosteroid injections have been shown to cause HSK reactivation, the role of topical steroid drops is less clear. ${ }^{85}$ Still, there is a theoretical risk for HSK reactivation with the use of topical steroids and, thus, for PRK and SMILE, we suggest continuing acyclovir or valacyclovir concurrently with steroid drops. If patient compliance is a concern, Miserocchi et al reported no difference in HSK recurrence between acyclovir or valacyclovir. ${ }^{86}$ Thus, valacyclovir $500 \mathrm{mg}$ once daily is an appropriate choice for prophylaxis. If there is a concern for resistance due to previously failed prophylaxis or prolonged disease course despite treatment, we recommend that these patients be strongly counseled to avoid corneal refractive surgery due to the higher risk of HSK reactivation.

\section{Conclusion}

Although rare, HSK reactivation can occur following corneal refractive procedures. This is significant as recurrence leads to worse visual outcomes. Nevertheless, not all patients with previous ocular HSV should be precluded from surgery. Patients with previous HSK who have been disease-free for at least one year, have no signs of active infection, and are managed prophylactically may be considered for corneal refractive surgery. As with every operation, each patient should be counseled on the risks and benefits of the procedure. Still, the literature regarding HSK prophylaxis before and after surgery is lacking. With more animal studies and randomized control trials, ophthalmologists will be better able to counsel their patients regarding operations that could significantly improve visual acuity.

\section{Acknowledgments}

This review article is based on previously published studies. Therefore, no IRB approval was required.

\section{Author Contributions}

All authors made substantial contributions to conception and design as well as analysis and interpretation of data; took part in drafting the article or revising it critically for important intellectual content; agreed to submit to the current journal; gave final approval of the version to be published; and agree to be accountable for all aspects of the work.

\section{Funding}

This study was funded by an unrestricted grant from Research to Prevent Blindness (RPB), 360 Lexington Avenue, 22nd Floor, New York, NY 10017. No support was received for the publication of this article.

\section{Disclosure}

None of the authors have any conflict of interest related to this work.

\section{References}

1. Farooq AV, Shukla D. Corneal latency and transmission of herpes simplex virus-1 [Internet]. Future Virol. 2011;6(1):101-108. doi: $10.2217 /$ fvl.10.74

2. White ML, Chodosh J. Herpes simplex virus keratitis: a treatment guideline - 2014 - American Academy of Ophthalmology [Internet]. Clin Stat. 2014.

3. Austin A, Lietman T, Rose-Nussbaumer J. Update on the management of infectious keratitis. Ophthalmology. 2017;124(11):16 78-1689. doi:10.1016/j.ophtha.2017.05.012

4. Darougar S, Wishart MS, Viswalingam ND. Epidemiological and clinical features of primary herpes simplex virus ocular infection. Br J Ophthalmol. 1985;69(1):2-6. doi:10.1136/bjo.69.1.2

5. Liesegang TJ. Herpes simplex virus epidemiology and ocular importance. Cornea. 2001;20:1-13. doi:10.1097/00003226-200101 000-00001

6. Reynaud C, Rousseau A, Kaswin G, M'garrech M, Barreau E, Labetoulle M. Persistent impairment of quality of life in patients with herpes simplex keratitis. In: Ophthalmology. Elsevier Inc.; 2017:160-169.doi:10.1016/j.ophtha.2016.10.001

7. Knickelbein JE, Hendricks RL, Charukamnoetkanok P. Management of herpes simplex virus stromal keratitis: an evidence-based review. Surv Ophthalmol. 2009;54(2):226-234. doi:10.1016/j.survophthal.20 08.12.004

8. Young RC, Hodge DO, Liesegang TJ, Baratz KH. Incidence, recurrence, and outcomes of herpes simplex virus eye disease in Olmsted County, Minnesota, 1976-2007: the effect of oral antiviral prophylaxis. Arch Ophthalmol. 2010;128(9):1178-1183. doi:10.1001/ archophthalmol.2010.187

9. Wilhelmus KR, Beck RW, Moke PS, et al. Acyclovir for the prevention of recurrent herpes simplex virus eye disease. $N$ Engl $J$ Med. 1998;339(5):300-306. doi:10.1056/NEJM199807303390 503

10. Cohen F, Cole SR, Beck RW, et al. Psychological stress and other potential triggers for recurrences of herpes simplex virus eye infections. Arch Ophthalmol. 2000;118(12):1617-1625.

11. Dhaliwal DK, Barnhorst DA, Romanowski E, Rehkopf PG, Gordon YJ. Efficient reactivation of latent herpes simplex virus type 1 infection by excimer laser keratectomy in the experimental rabbit ocular model. Am J Ophthalmol. 1998;125(4):488-492. doi:10. 1016/S0002-9394(99)80189-5

12. Dhaliwal DK, Romanowski EG, Yates KA, Hu D, Goldstein M, Gordon YJ. Experimental laser-assisted in situ keratomileusis induces the reactivation of latent herpes simplex virus. Am J Ophthalmol. 2001;131(4):506-507. doi:10.1016/S0002-9394(00)00811-4

13. Chuck RS, Jacobs DS, Lee JK, et al. Refractive errors \& refractive surgery preferred practice pattern ${ }^{\circledR}$. Ophthalmology. 2018;125(1):P1104. doi:10.1016/j.ophtha.2017.10.003

14. Mohammadpour M, Jabbarvand M. LASIK stromal versus epithelial herpetic keratitis. J Cataract Refract Surg. 2008;34(5):718. 
15. Jarade EF, Tabbara KF. Laser in situ keratomileusis in eyes with inactive herpetic keratitis. Am J Ophthalmol. 2001;132(5):779-780. doi:10.1016/S0002-9394(01)01092-3

16. De Rojas Silva MV, Díez-Feijóo E, Javaloy J, Sánchez-Salorio M. Prophylactic perioperative antiviral therapy for LASIK in patients with inactive herpetic keratitis. J Refract Surg. 2006;22(4):404-406. doi:10.3928/1081-597X-20060401-19

17. DeRojas Silva, R. Rodríguez-Conde, et al. Laser in situ keratomileusis in patients with a history of ocular herpes. J Cataract Refract Surg. 2007;33:1855-1859. doi:10.1016/j.jcrs.2007.07.014

18. Rao SK, Mukesh BN, Bakshi H, Sitalakshmi G, Padmanabhan P. Photorefractive keratectomy: the Sankara Nethralaya experience. Ophthalmic Surg Lasers. 1996;27(5 SUPPL).

19. McDonnell PJ, Moreira H, Clapham TN, D'arcy J, Munnerlyn CR. Photorefractive keratectomy for astigmatism: initial clinical results. Arch Ophthalmol. 1991;109(10):1370-1373. doi:10.1001/archopht. 1991.01080100050041

20. Nagy ZZ, Keleman E, Kovacs A. Herpes simplex keratitis after photorefractive keratectomy. J Cataract Refract Surg. 2003; 29:222-223. doi:10.1016/S0886-3350(02)02014-X

21. Wulff K, Fechner PU. Herpes simplex keratitis after photorefractive keratectomy. J Refract Surg. 1997;13:613.

22. Pepose JS, Laycock KA, Miller JK, et al. Reactivation of latent herpes simplex virus by excimer laser photokeratectomy. Am $J$ Ophthalmol. 1992;114(1):45-50. doi:10.1016/S0002-9394(14)77 411-2

23. Asbell PA. Valacyclovir for the prevention of recurrent herpes simplex virus eye disease after excimer laser photokeratectomy. In: Transactions of the American Ophthalmological Society [Internet]. American Ophthalmological Society; 2000;98:285-303. doi:10.1016/ s0002-9394(01)00945-x

24. Perna JJ, Mannix ML, Rooney JF, Notkins AL, Straus SE. Reactivation of latent herpes simplex virus infection by ultraviolet light: a human model. J Am Acad Dermatol. 1987;17(3):473-478. doi:10.1016/S0190-9622(87)70232-1

25. Moshirfar M, Welling JD, Feiz V, Holz H, Clinch TE. Infectious and noninfectious keratitis after laser in situ keratomileusis occurrence, management, and visual outcomes. $J$ Cataract Refract Surg. 2007;33:474-483. doi:10.1016/j.jcrs.2006.11.005

26. Labetoulle M, Auquier P, Conrad H, et al. Incidence of herpes simplex virus keratitis in France. Ophthalmology. 2005;112 (5):888-895. doi:10.1016/j.ophtha.2004.11.052

27. Sher NA, Bowers RA, Zabel RW, et al. Clinical use of the 193-nm excimer laser in the treatment of corneal scars. Arch Ophthalmol. 1991;109(4):491-498. doi:10.1001/archopht.1991.01080040059027

28. Fagerholm P, Öhman L, Örndahl M. Phototherapeutic keratectomy in herpes simplex keratitis: clinical results in 20 patients. Acta Ophthalmol. 1994;72(4):457-460. doi:10.1111/j.1755-3768.1994. tb02796.x

29. Tervo T, Tuunanen T. Excimer laser and reactivation of herpes simplex keratitis [Internet]. Eye Contact Lens. 1994;20:152-157. doi:10.1097/00140068-199407000-00004

30. Lu CK, Chen KH, Lee SM, Hsu WM, Lai JY, Li YS. Herpes simplex keratitis following excimer laser application. J Refract Surg. 2006;22 (5):509-511. doi:10.3928/1081-597X-20060501-15

31. Vrabec MP, Anderson JA, Rock ME, et al. Electron microscopic findings in a cornea with recurrence of herpes simplex keratitis after excimer laser phototherapeutic keratectomy. CLAO Journal. 1994;20:41-44.

32. Vrabec MP, Durrie DS, Chase DS. Recurrence of herpes simplex after excimer laser keratectomy [1]. Am J Ophthalmol. 1992;1 14:96-97. doi:10.1016/S0002-9394(14)77418-5

33. Deai T, Fukuda M, Tomoda Y, Higaki S, Hayashi K, Shimomura Y. Excimer laser photokeratectomy reactivates latent herpes simplex virus. Jpn J Ophthalmol. 2004;48(6):570-572. doi:10.1007/s10384004-0112-9
34. Starr M, Donnenfeld E, Newton M, Tostanoski J, Muller J, Odrich M. Excimer laser phototherapeutic keratectomy. Cornea. 1996;15 (6):557-565. doi:10.1097/00003226-199611000-00004

35. Beck RW, Asbell PA, Cohen EJ, et al. Oral acyclovir for herpes simplex virus eye disease: effect on prevention of epithelial keratitis and stromal keratitis. Arch Ophthalmol. 2000;118 (8):1030-1036.

36. Perng G-C, Osorio N, Jiang X, et al. Large amounts of reactivated virus in tears precedes recurrent herpes stromal keratitis in stressed rabbits latently infected with herpes simplex virus. Curr Eye Res. 2015;41(3):1-8. doi:10.3109/02713683.2015.1020172

37. Goto S, Koh S, Toda R, et al. Interface fluid syndrome after laser in situ keratomileusis following herpetic keratouveitis ASCRS and ESCRS. J Cart Refract Surg. 2013;39:1267-1270. doi:10.1016/j. jcrs.2013.04.026

38. Nakano EM, Kuchembuck M, Nakano K, Oliveira M, Alvarenga LS, Portellinha W. Coleção fluídica na interface do LASIK causada por glaucoma secundário à ceratouveíte herpética: relato de caso. Arq Bras Oftalmol. 2007;70(1):165-167. doi:10.1590/S0004-27492007000100032

39. Jain V, Pineda R. Reactivated herpetic keratitis following laser in situ keratomileusis. J Cataract Refract Surg [Internet]. 2009; 35 (5):946-948. Available from: http://scielo.isciii.es/scielo.php? scriptZ. Accessed November 05, 2020.

40. Orucoglu F, Aksu A. Late disciform endotheliitis after LASIK/ LASIK sonrasi gec donem diskiform endoteliyitis. Turk J Ophthalmol. 2013;43(4):282-286.

41. Arora T, Sharma N, Arora S, Titiyal JS. Fulminant herpetic keratouveitis with flap necrosis following laser in situ keratomileusis: case report and review of literature. J Cataract Refract Surg. 2014;40 (12):2152-2156. doi:10.1016/j.jcrs.2014.09.0180886-3350

42. Perry HD, Doshi SJ, Donnenfeld ED, Levinson DH, Douglas Cameron C. Herpes simplex reactivation following laser in situ keratomileusis and subsequent corneal perforation. CLAO J. 2002;28(2):69-71.

43. Gómez García S, Piñero Bustamante AM, Gutiérrez Sánchez E, Piñero Bustamante A. Herpes simplex keratitis following laser in situ keratomileusis. Arch Soc Esp Oftalmol. 2004;79(3):139-141. doi:10.4321/S0365-66912004000300009

44. Davidorf JM. Herpes simplex keratitis after LASIK [1]. J Refract Surg. 1998;14:667.

45. Kamburoglu G, Ertan A. Peripheral herpes simplex keratitis following LASIK [3]. J Refract Surg. 2007;23:742-743. doi:10.3928/1081597X-20071001-02

46. Levy J, Lapid-Gortzak R, Klemperer I, Lifshitz T. Herpes simplex virus keratitis after laser in situ keratomileusis. J Refract Surg. 2005;21(4):400-402. doi:10.3928/1081-597X-20050701-17

47. Srirampur A, Garg P, Amula G. Presumed Herpes simplex virus reactivation following LASIK mimicking diffuse lamellar keratitis. Asian J Ophthalmol. 2020.

48. Gupta V, Dada T, Vajpayee RB, Sharma N, Dada VK. Polymicrobial keratitis after laser in situ keratomileusis. J Refract Surg. 2001;17 (2):147-148.

49. Moshirfar M, McCaughey MV, Reinstein DZ, Shah R, SantiagoCaban L, Fenzl CR. Small-incision lenticule extraction. J Cataract Refract Surg. 2015;41(3):652-665. doi:10.1016/j.jcrs.2015.02.006

50. Sekundo W, Kunert KS, Blum M. Small incision corneal refractive surgery using the small incision lenticule extraction (SMILE) procedure for the correction of myopia and myopic astigmatism: results of a 6 month prospective study. Br J Ophthalmol. 2011;95(3):335-339. doi:10.1136/bjo.2009.174284

51. Guindolet D, Badaoui A, Elluard M, et al. Unusual severe interface inflammation after uneventful Small Incision Lenticule Extraction (SMILE). J Refract Surg. 2016;32(12):855-857. doi:10.3928/108159 7X-20161019-02

52. Kaye SB, Baker K, Bonshek R, et al. Human herpesviruses in the cornea. Br J Ophthalmol. 2000;84(6):563-571. doi:10.1136/bjo.84. 6.563 
53. Tan TE, Cheung CMG, Meht JS. Activation of Cytomegalovirus corneal endotheliitis following laser in situ keratomileusis. $B M J$ Case Rep. 2016;bcr2016216774. doi:10.1136/bcr-2016-216774

54. Jarade EF, Tabbara KF. Presumed reactivation of herpes zoster ophthalmicus following laser in situ keratomileusis. J Refract Surg. 2002;18(1):79-80.

55. Bacsal K, Chee SP. Uveitis-associated flap edema and lamellar interface fluid collection after LASIK [13]. Am $J$ Ophthalmol. 2006;141:232. doi:10.1016/j.ajo.2005.08.049

56. Kaufman SC. Use of photorefractive keratectomy in a patient with a corneal scar secondary to herpes zoster ophthalmicus. Ophthalmology. 2008;115(2):S33-4. doi:10.1016/j.ophtha.2007.10.014

57. Tran KD, Falcone MM, Choi DS, et al. Epidemiology of herpes zoster ophthalmicus recurrence and chronicity. Ophthalmology. 2016;123(7):1469-1475. doi:10.1016/j.ophtha.2016.03.005

58. Miserocchi E, Fogliato G, Bianchi I, Bandello F, Modorati G. Clinical features of ocular herpetic infection in an Italian referral center. Cornea. 2014;33(6):565-570. doi:10.1097/ICO.0000000000000129

59. Cohen EJ. Management and prevention of herpes zoster ocular disease. Cornea. 2015;34:S3-8. doi:10.1097/ICO.0000000000000503

60. Davis AR, Sheppard J. Herpes zoster ophthalmicus review and prevention. Eye Contact Lens Sci Clin Pract. 2019;45(5):286-291. doi:10.1097/ICL.0000000000000591

61. Sy A, McLeod SD, Cohen EJ, et al. Practice patterns and opinions in the management of recurrent or chronic herpes zoster ophthalmicus. Cornea. 2012;31(7):786-790. doi:10.1097/ICO.0b013e31823cbe6a

62. Suzuki T, Hara Y, Uno T, Ohashi Y. DNA of cytomegalovirus detected by PCR in aqueous of patient with corneal endotheliitis after penetrating keratoplasty. Cornea. 2007;26(3):370-372. doi:10.1097/ICO.0b013e31802d82fa

63. Zamir E, Stawell R, Jhanji V, Vajpayee RB. Corneal endotheliitis triggered by cataract surgery in a Chinese patient with cytomegalovirus anterior uveitis. Clin Experiment Ophthalmol. 2011;39: 913-915. doi:10.1111/j.1442-9071.2011.02577.x

64. Chan NSW, Chee SP, Caspers L, Bodaghi B. Clinical features of CMV-associated anterior uveitis. Ocul Immunol Inflamm. 2018;26 (1):107-115. doi:10.1080/09273948.2017.1394471

65. Koizumi N, Inatomi T, Suzuki T, et al. Clinical features and management of cytomegalovirus corneal endotheliitis: analysis of 106 cases from the Japan corneal endotheliitis study. J Ophthalmol. 2015.

66. Eduardo-Sánchez YW, Fernández-Agrafojo D. Human immunodeficiency virus-associated giant conjunctival Kaposi's sarcoma: complete remission with antiretroviral therapy and systemic chemotherapy. Arch La Soc Española Oftalmol (English Ed). 2018;93(6):310-312. doi:10.1016/j.oftal.2017.07.010

67. Starr MB. Recurrent subepithelial corneal opacities after excimer laser phototherapeutic keratectomy. Cornea. 1999;18(1):117-120. doi:10.1097/00003226-199901000-00018

68. Dhaliwal DK, Romanowski EG, Yates KA, et al. Valacyclovir inhibition of recovery of ocular herpes simplex virus type 1 after experimental reactivation by laser in situ keratomileusis. $J$ Cataract Refract Surg. 2001;27(8):1288-1293. doi:10.1016/S0886-3350(01)00804-5

69. Sykakis E, Karim R, Parmar DN. Management of patients with herpes simplex virus eye disease having cataract surgery in the United Kingdom. J Cart Refract Surg. 2013;39:1254-1259. doi:10.1016/j.jcrs.2013.06.005
70. Yu AC, Friehmann A, Myerscough J, et al. Initial high-dose prophylaxis and extended taper for mushroom keratoplasty in vascularized herpetic scars. Am J Ophthalmol. 2020;217:212-223. doi:10.1016/j. ajo.2020.04.016

71. Goldblum D, Bachmann C, Tappeiner C, Garweg J, Frueh BE. Comparison of oral antiviral therapy with valacyclovir or acyclovir after penetrating keratoplasty for herpetic keratitis. Br J Ophthalmol. 2008;92(9):1201-1205.

72. Zhang YM, Wu SQ, Yao YF. Long-term comparison of full-bed deep anterior lamellar keratoplasty and penetrating keratoplasty in treating keratoconus. $J$ Zhejiang Univ Sci B. 2013;14(5):438-450. doi:10. 1631/jzus.B1200272

73. Roozbahani M, Hammersmith KM. Management of herpes simplex virus epithelial keratitis. Curr Opin Ophthalmol. 2018;29:360-364. doi:10.1097/ICU.0000000000000483

74. Van Velzen M, Van De Vijver DAMC, Van Loenen FB, Osterhaus ADME, Remeijer L, Verjans GMGM. Acyclovir prophylaxis predisposes to antiviral-resistant recurrent herpetic keratitis. J Infect Dis. 2013;208(9):1359-1365. doi:10.1093/infdis/jit350

75. Rousseau A, Boutolleau D, Titier K, et al. Recurrent herpetic keratitis despite antiviral prophylaxis: a virological and pharmacological study. Antiviral Res. 2017;146:205-212. doi:10.1016/j.antiviral.2017.09.013

76. Duan R, De Vries RD, Osterhaus ADME, Remeijer L, Verjans GMGM. Acyclovir-resistant corneal HSV-1 isolates from patients with herpetic keratitis. J Infect Dis. 2008;198(5):659-663. doi: $10.1086 / 590668$

77. Choong K, Walker NJ, Apel AJ, Whitby M. Aciclovir-resistant herpes keratitis. Clin Exp Ophthalmol. 2010;38(3):309-313. doi:10.1111/j.1442-9071.2010.02209.x

78. Sibley D, Larkin DFP. Update on Herpes simplex keratitis management. Eye (Basingstoke). 2020;1-8. doi:10.1038/s41433-020-01153-x

79. Wilcox CL, Johnson EM. Nerve growth factor deprivation results in the reactivation of latent herpes simplex virus in vitro. $J$ Virol. 1987;61(7):2311-2315. doi:10.1128/JVI.61.7.2311-2315.1987

80. Tervo K, Latvala TM, Tervo TMT. Recovery of corneal innervation following photorefractive keratoablation. Arch Ophthalmol. 1994;112 (11):1466-1470. doi:10.1001/archopht.1994.01090230080025

81. Rowe AM, St. Leger AJ, Jeon S, Dhaliwal DK, Knickelbein JE, Hendricks RL. Herpes keratitis. Prog Retin Eye Res. 2013;32:88-101. doi:10.1016/j.preteyeres.2012.08.002

82. Cunningham AL, Diefenbach RJ, Miranda-Saksena M, et al. The cycle of human herpes simplex virus infection: virus transport and immune control. J Infect Dis. 2006;194(s1):S11-S18. doi:10.1086/505359

83. Kaufman HE, Azcuy AM, Varnell ED, Sloop GD, Thompson HW, Hill JM. HSV-1 DNA in tears and saliva of normal adults. Investig Ophthalmol Vis Sci. 2005;46(1):241-247. doi:10.1167/iovs.04-0614

84. Kaye S, Choudhary A. Herpes simplex keratitis. Prog Retin Eye Res. 2006;25:355-380. doi:10.1016/j.preteyeres.2006.05.001

85. Fung AT, Tran T, Lim LL, et al. Local delivery of corticosteroids in clinical ophthalmology: a review. Clin Experiment Ophthalmol. 2020;48:366-401.

86. Miserocchi E, Modorati G, Galli L, Rama P. Efficacy of valacyclovir vs acyclovir for the prevention of recurrent herpes simplex virus eye disease: a pilot study. Am J Ophthalmol. 2007;144(4):547-551.e1. doi:10.1016/j.ajo.2007.06.001 


\section{Publish your work in this journal}

Clinical Ophthalmology is an international, peer-reviewed journal covering all subspecialties within ophthalmology. Key topics include: Optometry; Visual science; Pharmacology and drug therapy in eye diseases; Basic Sciences; Primary and Secondary eye care; Patient Safety and Quality of Care Improvements. This journal is indexed on PubMed
Central and CAS, and is the official journal of The Society of Clinical Ophthalmology (SCO). The manuscript management system is completely online and includes a very quick and fair peer-review system, which is all easy to use. Visit http://www.dovepress.com/ testimonials.php to read real quotes from published authors.

Submit your manuscript here: https://www.dovepress.com/clinical-ophthalmology-journal 